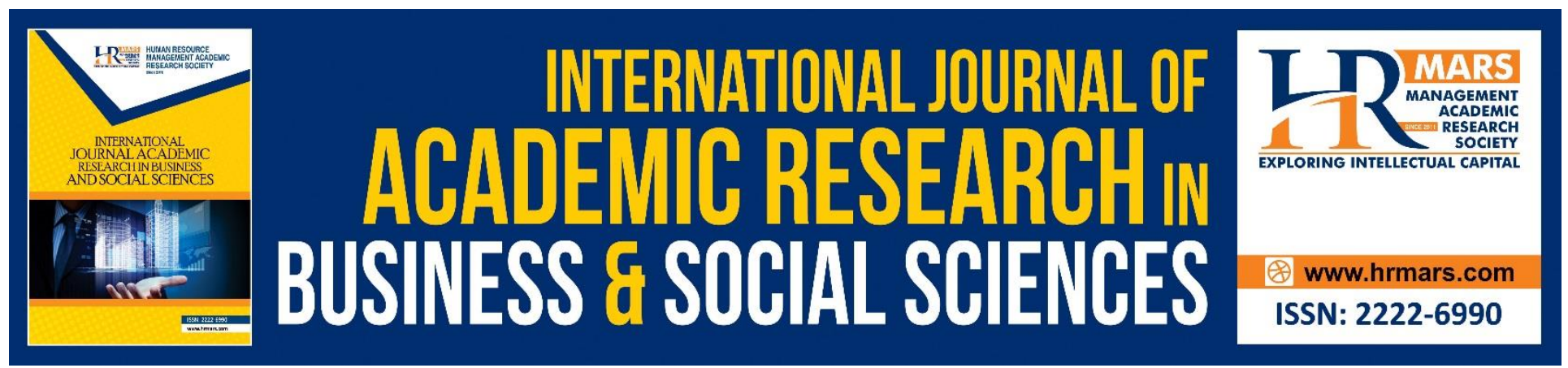

\title{
The Effect of Organizational Competencies on Organizational Competitive Advantage of the Banking Sector in Kenya
}

\author{
Prisca Jepkemboi Choge, Gregory Namusonge, Elizabeth Nambuswa \\ Makokha, Enock Gideon Musau
}

To Link this Article: http://dx.doi.org/10.6007/IJARBSS/v8-i10/4776

DOI: $10.6007 /$ IJARBSS/v8-i10/4776

Received: 10 Sept 2018, Revised: 07 Oct 2018, Accepted: 16 Oct 2018

Published Online: 23 October 2018

In-Text Citation: (Choge, Namusonge, Makokha, \& Musau, 2018)

To Cite this Article: Choge, P. J., Namusonge, G., Makokha, E. N., \& Musau, E. G. (2018). The Effect of Organizational Competencies on Organizational Competitive Advantage of the Banking Sector in Kenya. International Journal of Academic Research in Business and Social Sciences, 8(10), 739-760.

Copyright: (C) 2018 The Author(s)

Published by Human Resource Management Academic Research Society (www.hrmars.com)

This article is published under the Creative Commons Attribution (CC BY 4.0) license. Anyone may reproduce, distribute, translate and create derivative works of this article (for both commercial and non-commercial purposes), subject to full attribution to the original publication and authors. The full terms of this license may be seen

at: http://creativecommons.org/licences/by/4.0/legalcode

Vol. 8, No. 10, 2018, Pg. 739 - 760

http://hrmars.com/index.php/pages/detail/IJARBSS

JOURNAL HOMEPAGE

Full Terms \& Conditions of access and use can be found at http://hrmars.com/index.php/pages/detail/publication-ethics 


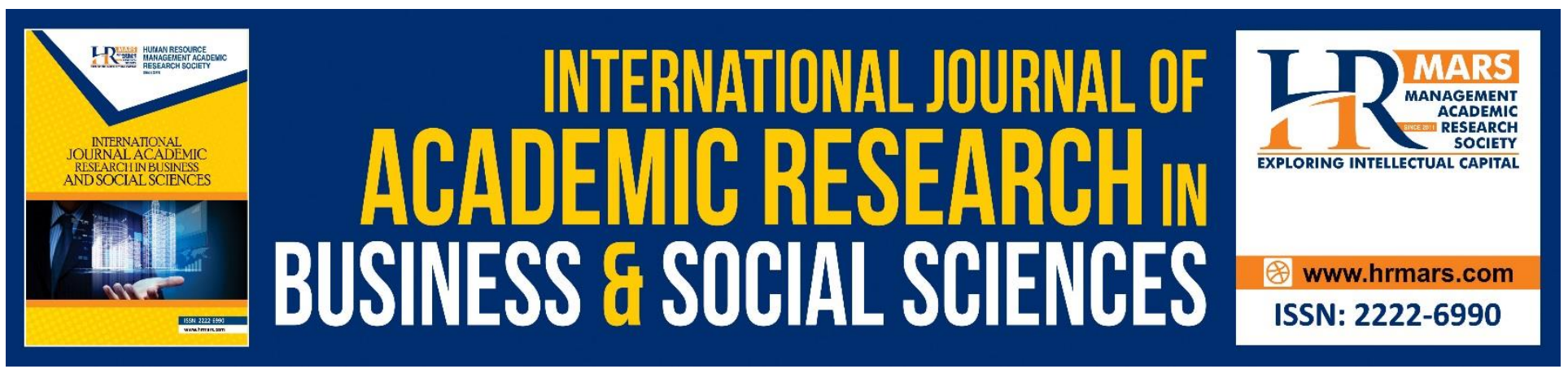

\title{
The Effect of Organizational Competencies on Organizational Competitive Advantage of the Banking Sector in Kenya
}

\author{
Prisca Jepkemboi Choge
}

PhD. Strategic management Candidate Jomo Kenyatta University of Agriculture and Technology, School of Entrepreneurship, Procurement and Management, Nairobi, Kenya

Email: priscachoge@gmail.com

\section{Professor. Gregory Namusonge}

Professor Jomo Kenyatta University of Agriculture and Technology, School of Entrepreneurship,

Procurement and Management, Nairobi, Kenya

Email: gsnamusonge@yahoo.co.uk

Dr. Elizabeth Nambuswa Makokha

Lecturer Jomo Kenyatta University of Agriculture and Technology, School of Entrepreneurship,

Procurement and Management, Nairobi, Kenya

Email: enambuswa@gmail.com

\section{Dr. Enock Gideon Musau}

Lecturer Jomo Kenyatta University of Agriculture and Technology, School of Entrepreneurship, Procurement and Management, Nairobi, Kenya

Email: egiddy14@gmail.com

\section{ABSTRACT}

The purpose of the study was to investigate the effect of organizational competencies on organizational competitive advantage of the banking sector in Kenya. The specific objective of the study was to; determine the effect of organizational competencies on organizational competitive advantage. This study was informed by resource based theory, stakeholder theory and Michael Porter's theory of competitive advantage. The study employed explanatory research design. The survey was carried out in 25 banks within Eldoret town, Uasin - Gishu County. The target population was 748 respondents. A two stage sampling technique was used whereby cluster sampling techniques was used to select the banks, thereafter; simple random sampling was a used to select 
sample of 261 respondents from a population. Sample size was calculated using Yamane formula and distributed within the clusters according to Neyman allocation formula. Structured questionnaire was used to collect primary data while secondary data was obtained from published sources such as library, internet and research done by other scholars. Data was analysed using descriptive and inferential statistics. Descriptive statistics like frequencies, mean and standard deviation were used. For inferential statistics, ANOVA and linear Regression were used.The outcome was a probability of $\mathrm{R}^{2}=0.620$ which means there was 62.0 percent probability of organizational competencies predicting competitive advantage. Organization competencies had positive and significant B values of .565. It also had a positive and significant correlation of .787 with competitive advantage. The study recommends that organizational competencies as a predictor of competitive advantage should be ingrained in the organization policies to foment competitive advantage. Thus, banks should embrace competencies and strategically align them to organization policies for competitive advantage.

Keywords: Transport management, organizational performance and Manufacturing firms

\section{Introduction}

Competencies are an important source of competitive advantage however many firms encounter difficulties when they attempt to identify and assess those competencies (Adelaide, Sally, \& Carl, 2001). In fine Core competencies allow organizations to deliver value to their customers (Basu, 2018). Notwithstanding, Competency should be difficult and costly to imitate to guarantee an organizations competitive edge amongst its competitors.Besides competencies should be embedded in firms missions, culture or values to make them immobile (King, Fowler, \& Zeithaml, 2001).

Competence is the knowledge set that distinguishes a firm and provides a competitive advantage over others (Agha, Alrubaiee, \& Jamhour, 2011). Macharia, (2014) avers that the fulcrum of efficient strategic management is the alignment of strategy, organizational competencies and resources. The crafting of a strategy represents a organizational competence in pursuing idiosyncratic actions which sets them apart in conducting operations, and improving the company's financial and market performance thus competitive advantage. According to Thomas (2001) competency concept has something more to offer than the RBV in that competence enable firm leverage the resources and assets at hand. This is ascribed to the fact that the firm should have the competence of tapping sources of resources and assets and bundling them into products and services for customer satisfaction. However harmonization and synergy of distinctive competencies and strategies in banks may be obscured by ambiguity and significant variation of individual perceptions of a firm's competencies. This explains differences in firm level of competences which are imbedded in assets, processes and paths which result in competitive advantage and performance (Teece D. J., 2007). Performance is influenced by various factors, among them the drivers of competitive advantage (Jiao, Wei, \& Cui, 2010).

Banking environment is characterized by different banking products, increased choices, security and accessibility. In this regard Kathuni and Mugenda (2012) posits that players in this sector have experienced increased competition over the last few years resulting from increased innovations among the players and new entrants into the market. Thus, the ability of commercial banks to 
effectively and efficiently deliver products and services key to their performance is hinged on their competencies (Mwangi, 2016). Besides survival of commercial banks in Kenya is relies on the adoption of rare and non imitable organizational competencies as a competitive strategy to establish sustainable and profitable position against their competitors. Identification of competitive business strategies has become a priority to the banks' management since these have become an integral component of any business venture, in order for it to survive within an industry (Brown, Goetzmann, Liang, \& Schwarz, 2009). Some commercial banks have managed to secure an advantageous competitive position while others have not (Maina \& Manyara, 2004). However there is still enormous untapped potential by banks that can enhance Kenya's economy further.

Most local commercial banks lack the competencies to continuously update their core systems which hiders them from competing globally (Ngumi, 2013). By identifying their core competencies banks are able to focus on areas that give them an advantage over their competitors (Nthambi \& Ogollah, 2017). Although a firm may identify a host of competences that it performs better relative to its competitors, not all competences are "core". This underscores the varying importance of competence dimensions on competitive advantage and organizational performance (Agha, Alrubaiee, \& Jamhour, Effect of core competence on competitive advantage and organizational performance. , 2011). Competencies also influences the company's CSR performance in addition to important institutional and organizational factors and processes (Osagie \& Wesselink, 2014). Companies are likely to be different in terms of their abilities to select, build, deploy, and protect this core Competencies. These differences are likely to yield differences in corporate performance. This altogether has motivated the need to assess the effect on organizational competence on competitive advantage in commercial banks.

\section{Statement of the Problem}

Competitive advantage is important and firms throughout the world currently face slower growth and no longer act as if the expanding pie were big enough for all (Klein, 2001). The essence of competitive strategies for profitability and sustainability against the forces of competition cannot be gainsaid. This is underscored by the fact that the strategies employed by the banks dictate their competitive advantage (Mwangi, 2015). However, banks operate within a web of complex and competing interests with diverse expectations which require strategies of balancing and weighing the impact of their decisions (Desta, 2010).Cavazotte and Chang (2016) opine that companies which neglect their internal social responsibilities like developing human resource competencies are likely to experience negative consequences thwarting their competitive advantage.

The banking sector remains crucial in delivering the envisioned 10 percent economic growth rate per annum in Kenya (Kariuki, 2015). However, banks have experienced increased competition over the last few years due to increased innovations among the players and new entrants into the market (PWC Kenya, 2011). Thus, Kenyan banks exhibit differences in performance, with some banks reporting profits while others report losses in their annual report (Oloo, 2011; CBK, 2012). This has an immense implication on the economic growth of the country. This compels banks to enhance their competitive advantage in agreement with Porters (1991) drivers of competitive advantage which 
view superior position, superior skills and superior resources as drivers. Thus the use competencies as a differentiation attribute for competitive advantage. Competencies highlight specific facets of internal social investments that are likely to drive such outcomes (Cavazotte \& Chang, 2016 ). Companies are likely to be different in terms of their abilities to select, build, deploy, and protect this core Competencies. These differences are likely to yield differences in corporate performance. Therefore the study sought to fill the existing gap in literature by examining the effect of strategic competencies on banks competitive advantage in the Kenyan context.

\section{Objective of the study}

To determine the effect of organizational competencies on organizational competitive advantage in the banking sector in Kenya.

\section{Hypothesis}

The study was guided by the following null hypothesis:

$\mathbf{H}_{0} \mathbf{1}$ Organizational competencies do not have significant effect on organizational competitive advantage in the banking sector in Kenya

\section{LITERATURE REVIEW}

The study was guided by the following theories

\section{The Resource-Based View (RBV)}

The resource-based view (RBV) has emerged as a popular theory of competitive advantage (Furrer, Tomas \& Goussevskaia, 2008). The origins of the RBV go back to Penrose cited in Stefan (2012), who suggested that the resources possessed, deployed and used by the organization are really more important than industry structure. The term 'resource-based view' was coined much later by Werner felt as cited in Priem and Butler (2001) who viewed the firm as a bundle of assets or resources which are tied semi-permanently to the firm. Researchers subscribing to the RBV argue that only strategically important and useful resources and competencies should be viewed as sources of competitive advantage (Barney cited in (Raduan, Jegak, Haslinda \& Alimin, 2009). A firm achieves competitive advantage when the firm acquires or develops a resource or combination of resources that allows it to outperform its competitors (George, Stephen, Kibet, Elijah \& Fred, 2013) and uses such a resource strategically.

Barney cited in Rose, Abdullah and Ismad (2010) outlined four empirical indicators of the potential of firm resources to generate sustained competitive advantage - value, rareness, immutability and substitutability. On the other hand, Wang (2004) outlines an approach to firm-level analysis that requires stocktaking of a firm's internal assets and capabilities. The assets in question could be physical assets, knowledge assets (intellectual capital) as well as human resources, which in turn determine the capabilities of a firm. Maier and Remus (2002) use the term 'resource strategy' and define three steps in a firm's resource strategy - competence creation, competence realization and competence transaction. Other researchers like Barney and Wright cited in Wright, Dunford and Snell (2005) treated human resources as the most valuable type of resource. Dyer and Singh (1998) as well as Wang (2004) suggested that the link between the individual firm and the network of relationship in which the firm is embedded is important for competitive advantage. 
According to McWilliams, Siegel and Wright (2006)a firm must use organization competencies strategically so as to benefit the firm. Engaging in ICSR can help firms to create some of these resources and capabilities McWilliams, Siegel and Wright (2006) but how firms give substance to CSR is possible with different approaches (Porter \& Kramer, 2006). It is these different approaches that the study addressed so as to investigate the effect of strategic internal CSR on competitive advantage of the banking sector in Kenya.

\section{Edward Freeman's Stakeholder Theory on CSR}

While opposing Friedman's views that "the business of business is business", Freeman proposed a stakeholder approach to strategic management (Freeman, 2010). At the heart of this view is the stakeholder, which is a spin on the word shareholder, which means it is "any group or individual who can affect or is affected by the achievement of the organization's objectives". Freeman argues that stakeholder theory begins with the assumption that ethics are necessarily and explicitly a part of doing business. It asks managers to articulate the shared sense of the value they create and that which brings its core stakeholders together. Further, it pushes managers to be clear about how they want to do business, specifically what kinds of relationships they want and need to create with their stakeholders to deliver on their purpose (Freeman, Wicks \& Parmar, 2004). Hence, Freeman's stakeholder theory perceives that businesses are responsible for more than profit maximization for shareholders.

Stakeholder theory is concerned with evaluating the various stakeholders that the firm is perceived to be responsible to. It is mainly concerned with morals and values while managing an organization. According to this theory, a firm has various stakeholders to whom it is responsible to. Some of these stakeholders are the internal stakeholders who are its employees. When a firm concerns itself with the welfare of its employees, it will be engaging in internal corporate social responsibility. It aims at evaluating the various parties that have a claim over the firm. A firm is a collection of various stakeholders who have diverse requirements from the firm (Freeman, 2010). This theory models the various stakeholders into groups with diverse interests who are to be taken into consideration by the company while devising some ways of incorporating their various interests. This view is commonly advocated through stakeholder theory which maintains that corporations should consider the effects of their actions upon the customers, suppliers, general public, employees and others who have a stake or interest in the corporation (Cheers, 2011). Supporters of this theory reason that by providing for the needs of stakeholders, corporations ensure their continued success and thus, competitive advantage. A renowned company that exhibits the stakeholder view is Johnson and Johnson. They list the corporation's responsibilities in the following order: customers, employees, management, communities, and stockholders (Cheers, 2011).

\section{Michael Porter's Theory of Competitive Advantage}

Michael Porter defined the types of competitive advantage an organization can achieve relative to its rivals, that is, lower cost or cost leadership, focus and differentiation. This advantage derives from attributes that allow an organization to outperform its competition, such as superior market position, 
skills, or resources. In Porter's view, strategic management should be concerned with building and sustaining competitive advantage (Warf \& Stutz, 2007). Competitive advantage starts with the premise that competitive advantage can arise from many sources, and shows how all advantages can be connected to specific activities and the way that activities relate to each other, to supplier activities, and to customer activities (Porter, 1985). Internal factors within an organization aligned strategically to corporate social responsibility, are some of the sources which a firm can use to position itself advantageously in light of competition in the industry.

Porter cited in Chew and Gottschalk (2013) stated that resources are not valuable in and of them, but because they allow firms to perform activities that create advantages in particular markets when used strategically. Similarly, Bridoux (2004) argues that many organizational capabilities emerge, are refined, or decay as a result of product market activity. Porter, thus, proposes an analytical framework to assess the attractiveness of an industry whereby the group of firms producing products that are close substitutes for each other are considered. He identifies five basic competitive forces seen as threats to the firm profits: threat of entry, threat of substitution, bargaining power of buyers, bargaining power of suppliers, and rivalry among current competitors. The collective impact of these five forces, the underlying structure of an industry determines the intensity of industry competition and ability of firms in the industry to make profits. Porter describes competitive strategy as taking defensive and offensive actions to cope successfully with the five competitive forces. Porter's strategy is about positioning a business in a given industry structure, while the reality of business during the 1990's is that industry structures are far from stable and are undergoing major transitions (Bridoux, 2004).

\section{CONCEPTUAL FRAMEWORK}

A conceptual framework is an analytical tool with several variations and contexts used to make conceptual distinctions and organize ideas (Shields \& Rangarjan, 2013). Conceptual framework shows the way ideas are organized to achieve a research project's purpose. This study conceptualizes the relationship between organizational competencies with competitive advantage.

Organizational competencies are a facet of ICSR and refer to companies' commitment to contributing to sustainable relations with their employees, so that their actions have a positive effect on business and on development (Cavazotte \& Chang, 2016 ). It is presumed that when a company has the capacity to attract talent courtesy of its responsibility to its employees, then this would certainly translate into competitive advantage. This can be strategic for companies, since human capital acquisition risks pose threats to productivity, as well as turnover and replacement costs which precipitates competitive disadvantage (Brymer, Molloy \& Gilbert, 2014).

Organization competencies as intangible assets seem to be especially relevant to the development of competitive advantage (Barney, 2001). In this study organizational competencies were measured in terms of Knowledge, training and development and capabilities, adopted from (Hummaira, Iftikhar,Ali \& Muhammad, 2016). Once an organization has a clear understanding of its required organizational competencies, management evaluates them to determine what combination of 
INTERNATIONAL JOURNAL OF ACADEMIC RESEARCH IN BUSINESS AND SOCIAL SCIENCES Vol. 8, No. 10, Oct. 2018, E-ISSN: 2222-6990 @ 2018 HRMARS

employees, skills, processes, systems, facilities, partnerships can be used strategically to maintain organizational effectiveness and competitive advantage.

The resource-based view stipulates that in strategic management, the fundamental sources and drivers of firms' competitive advantage and superior performance are mainly associated with the attributes of their resources and capabilities, which are both valuable and costly-to-copy (Ali \& Abdülkadir, 2015 ). In this study the conceptual work of Porter (1980), Scherer (1980), Miles and Snow (1978) and MacMillan and Hambrick (1983), which measured competitive advantage in terms of dimensions that reflect important competitive strategies like differentiation, cost leadership, focus and asset parsimony are used (Macharia, 2014). The conceptual framework is shown in the figure below:

Independent Variable

\begin{tabular}{|c|c|}
\hline $\begin{array}{l}\text { Organizational Competencies } \\
\text { - Knowledge } \\
\text { - Training and development } \\
\text { - Capabilities }\end{array}$ & $\begin{array}{l}\text { Competitive advantage } \\
\text { - Focus } \\
\text { - Differentiation } \\
\text { - Cost leadership }\end{array}$ \\
\hline
\end{tabular}

\section{Organizational Competencies on Competitive Advantage}

Knowledge is one of the competencies that organizations may have. While most researchers subscribing to the RBV regard knowledge as a generic resource, some researchers (Murray, 2000; Teece, Pisano, \& Shuen, 1997)suggest that knowledge has special characteristics that make it the most important and valuable resource. Hamel and Prahalad cited in Wang(2013) argue that knowledge, know-how, intellectual assets and competencies are the main drivers of superior performance in the information age. Cania and Korsita (2015) also suggest that knowledge is the most important resource of a firm. Evans cited inCania and Korsita(2015) pointed out that material resources decrease when used in the firm, while knowledge assets increase with use. This is actually an aspect of experience. With increased experience there is increased know-how. Tiwana cited in Cania and Korsita(2015) argued that technology, capital, market share or product sources are easier to copy by other firms while knowledge is the only resource that is difficult to imitate. This lack of imitability is the exact source of sustainable competitive advantage.

Sirmon cited in Sanifa (2015) stressed the importance of organizational learning. He suggested that capabilities and organizational learning implicitly and explicitly are a part of any strategy within a firm. It has been argued that the ability to learn and create new knowledge is essential for gaining competitive advantage. Lee and Pennings cited inSu; Tsang and Peng (2009) discussed the influence of internal capabilities and external networks on firm performance. Grant cited inBrown and Duguid(2001) on the other hand, argued that there are two types of knowledge: information and 
know-how. Beckmann cited inSu; Tsang and Peng (2009) proposed a five-level knowledge hierarchy comprising data, information, knowledge, expertise and capabilities. Zack cited inSu, Tsang and Peng (2009) divides organizational knowledge into three categories: core knowledge, advanced knowledge, and innovative knowledge. Core knowledge is the basic knowledge that enables a firm to survive in the market in the short-term. Advanced knowledge provides the firm with similar knowledge as its rivals and allows the firm to actively compete in the short term. Innovative knowledge gives the firm its competitive position over its rivals. The firm with innovative knowledge is able to introduce innovative products or services, potentially helping it become a market leader (Su, Tsang \& Peng, 2009).

Competence can also be viewed in terms of Capability Grant cited inBridoux (2004) argued that capabilities are the source of competitive advantage while resources are the source of capabilities. Amit and Shoemaker cited inSu, Tsang and Peng (2009) adopted a similar position and suggested that resources do not contribute to sustained competitive advantages for a firm, but its capabilities do. Haas and Hansen as well as well as Long and Vickers-Koch cited inWang (2014) supported the importance of capabilities and suggest that a firm can gain competitive advantage from its ability to apply its capabilities to perform important activities within the firm. Amit and Shoemaker cited in Su, Tsangand Peng(2009) defined capabilities in contrast to resources, as 'a firm's capacity to deploy resources, usually in combination using organizational processes, and affect a desired end. They are information-based, tangible or intangible processes that are firm-specific and developed over time through complex interactions among the firm's resources. Teece et al cited in Acıkdilli and Ayhan (2013) define dynamic capabilities as, 'the firm's ability to integrate, build, and reconfigure internal and external competencies to address rapidly changing environments'. Grant cited in Bridoux (2004) defines organizational capability as, 'a firm's ability to perform repeatedly a productive task which relates either directly or indirectly to a firm's capacity for creating value through effecting the transformation of inputs to outputs'. Dave and Dale (1991) assert that merely hiring the best people does not guarantee organizational capability. Hiring competent employees and developing those competencies through effective human resource practices, underpins organizational capability.

Agha, Alrubaiee and Jamhour(2011) in their study on investigating the relationship between core competence, competitive advantage and organizational performance, focused on the three dimensions of core competence: shared vision, cooperation and empowerment while competitive advantage was also measured through flexibility and responsiveness. The proposed model was tested in the context of Paint Industry in the UAE by administering the survey electronically to a total of 77 managers. Findings indicated that, while core competence has a strong and positive impact on competitive advantage and organizational performance, competitive advantage has also significant impact on organizational performance. Results confirm the varying importance of core competence dimensions on competitive advantage and organizational performance. It has also been found that flexibility have higher impact on organizational performance than responsiveness. To remain competitive and obtain competitive advantages, managers can try to increase organizational performance by managing each dimension of core competence i.e. shared vision; cooperation and 
INTERNATIONAL JOURNAL OF ACADEMIC RESEARCH IN BUSINESS AND SOCIAL SCIENCES Vol. 8, No. 10, Oct. 2018, E-ISSN: 2222-6990 @ 2018 HRMARS

empowerment. Flexibility and responsiveness for competitive advantage can be achieved by empowering employees through continuous employee training and development.

Bani-Hani and AL-Hawary (2009) in their study on the impact of core competencies on competitive advantage and it applied on Jordanian insurance organizations gives relevant outcome. The population for this study consisted of all the Jordanian insurance organizations heads. A simple random sampling technique was used to select the respondents surveyed for this study, a total of 61 questionnaires were administered to respondents chosen from 18 company; statistical tools were used to test the hypothesis such as: spearman correlation, and multiple regression. The findings indicated that there is a significant positive relationship between core competencies and competitive advantage from the sample point view.

Bahri, Yahya and Kusman (2015) determined the magnitude of the effect of Core Competencies variable toward competitive strategy and its impact on the performance of enterprises. The study used census method by taking the entire enterprises in the province of Aceh (thirty-one units) with eighty-eight respondents, including the director and the field director of the Local Government Owned Enterprises (BUMD). The Core Competence significantly affects Competitive advantage.

Nimsith, Rifas and Cader(2016) focused on the strategic role of core competencies on competitive advantage, applied by the banking firms in Sri Lanka. The study was conducted based on qualitative survey. Primary data was collected through structured questionnaire, which was distributed to select banking firms in Sri Lanka. The findings revealed that different banking firms have different areas which they consider as their core competencies; there is significant relationship between core competencies and competitive advantage among Sri Lankan banking firms.

Mugo (2016) established the effect of organizational core competencies on performance in the insurance industry in Kenya. The study adopted a descriptive research design with a target population 49 insurance companies registered with the association of Kenya insurers (AKI) by December 2014. The correlation results revealed that core competences promoted performance in the insurance industry in Kenya. The study recommend that the HR of insurance companies in Kenya needs to ensure that firm's policies encourage employee sense of belonging, policies that provide constant feedback on the positives and negatives, encourage open communication, and develop policies that communicate clear goals and expectations to the employees.

Jabbouri and Zahari (2014) studied the impact of core competencies on organizational performance as a critical issue in Iraqi private banking sector. The findings showed that there is a significant correlation among core competences and organizational performance. Based on this, their recommendation was that bank management should develop of the core competencies for human resource as a strategic tool to enhance organizational performance and expand their empirical knowledge in the context of private banks in Iraq. 
INTERNATIONAL JOURNAL OF ACADEMIC RESEARCH IN BUSINESS AND SOCIAL SCIENCES

Vol. 8, No. 10, Oct. 2018, E-ISSN: 2222-6990 @ 2018 HRMARS

\section{Research Gaps}

Most research on CSR has focused on the consequences of CSR implementation or lack of implementation on financial performance (Barnett \& Salomon, 2006; Moskolaï, 2016;Galant \& Cadez, 2017). Besides, studies have been conducted in the context of developed countries Ndinda, Namusonge and Kihoro (2015) which may not be generalized to developing countries which have an entirely different socio-political environment, with different political regimes, legal systems and cultural influences (Tilt, 2016). This is a dispatch of the focus of the current study which is competitive advantage. The study is specifically aligned towards the strategic use of organizational competencies and organizational competitive advantage.

Existing research shows that individuals and organizations are likely to have distinct expectations and attitudes towards CSR contingent on the industry Yuen and Lim, (2016); Batool, Butt and Niazi (2016)or societal culture and national cultures Gualtieri and Topić (2016) in which theyare embedded. Moreover, most of the studies have been conducted outside the African context and especially outside the Kenyan context. This, thus, provides a contextual gap which this study is going to address by looking at organizational competenciesand its effect on organizational competitive advantage in Kenya.This is justified by the fact that different cultural orientations cannot be used to explain and understand organizational problems of other countries. This calls for the organizations to set themselves apart through developing their own unique internal competencies that would give them an edge over their competitors. A study by McWilliams, Siegel and Wright (2005) cited in Velte and Stawinoga (2017) proposed an agenda for additional theoretical and empirical research on CSR. Despite research on CSR having spanned across a few decades and in various fields, only a handful of academic studies have investigated the relationship between CSR and the commonly neglected internal stakeholder - the employees (Mei \& Seng, 2015).This study therefore fills the existing theoretical, empirical and contextual gaps by assessing the effect organizational competencies on organizational competitive advantage in the banking sector in Kenya.

\section{RESEARCH METHODOLOGY}

The study employed explanatory research design. According to Cooper and Schindler (2008), explanatory research focuses on 'why' questions. In answering the 'why' questions, the study developed explanations. The explanations argue that phenomenon $Y$ (competitive advantage) is affected by variable $X$ (Competencies) and even showed the extent of the effect.

The target population consisted of748 employees drawn from 25 banks within Eldoret town, Uasin Gishu County. The employees were targeted because they were affected by the ICSR practices, like enhancement of competencies, employed by the banks and, as such, could give a feedback on the causal relationship between the study variables for purposes of generalization. The sample frame for this study was all the employees from the 25 banks in Uasin - Gishu County.

On Sample and Sampling Technique/Procedures, a two stage sampling technique was used to narrow down to the employees. Cluster sampling technique was used to select the banks. Cluster sampling refers to a type of sampling method in which the researcher divides the population into separate 
groups, called clusters (Pfeffermann \& Radhakrishna, 2009). Cluster sampling is a sampling plan used when mutually homogeneous yet internally heterogeneous groupings are evident in a statistical population. (Cameron \& Miller, 2015).

Individual banks represented clusters such that each bank would be proportionately represented depending on the size of its employees. Simple random sampling was used to select the respondents to participate in the research study, but after it had been determined how many from each of the banks was to participate. Simple random sampling (SRS) is a method of selection of a sample comprising of $\mathrm{n}$ number of sampling units out of the population having $\mathrm{N}$ number of sampling units such that every sampling unit has an equal chance of being chosen. (Collis \& Hussey, 2009).

A sample size of 261 was drawn from a total population of 748 employees to represent the whole population. From the target population of 748, Taro Yamane (1967), sample size formula modified by Kent and Myers (2008) as cited in Etuk and Akpabio (2014) was used to select a sample size of 261 employees as shown below:

Where:

$$
n=\frac{N}{1+N e^{2}}
$$

$$
\begin{aligned}
\mathrm{n} & =\text { Sample size } \\
\mathrm{N} & =\text { Population size } \\
\mathrm{e} & =\text { the error of Sampling }
\end{aligned}
$$

This study allowed the error of sampling of 0.05 . Thus, sample size will be as follows:

The sample size was distributed proportionally according to Neyman's allocation formula (Carfagna $\&$ Arti, 2007). The purpose of the method was to maximize survey precision, given a fixed sample size. With Neyman's allocation, the best sample size for cluster $\mathrm{h}$ would be:

Where,

$$
n_{h}=\left(\frac{N_{h}}{N}\right) n
$$

$n_{h^{-}}$The sample size for cluster $h$,

$\mathrm{n}$ - Total sample size,

$\mathrm{N}_{\mathrm{h}}$-The population size for cluster $\mathrm{h}$,

$\mathrm{N}$ - The total population

Hence, distribution was as follows; the respondents were selected using simple random sampling. Primary and secondary data was sought. A questionnaire was used to collect data. The questionnaire was introduced to the respondents to explain the researcher's purpose of the survey. The instructions required the respondents to indicate the extent to which they agreed, disagreed, or were neutral about the statements of constructs that were used to describe research variables.

Data Processing and Analysis was done. The initial data analysis was done by taking the distribution of scores and using simple descriptive statistical measures such as, percentages, means, standard deviation (measures of central tendencies) and variances to measure relationships. These helped to get a glimpse of the general trend.

Inferential statistics specifically Pearson product moment coefficient of correlation $(r)$ and multiple linear regression were used. Pearson product moment coefficient correlation was used to determine 
the extent to which ICSR affected competitive advantage of organizations. The beta $(\beta)$ coefficients for each independent variable were generated from the model, and analysis of variance (ANOVA) was used. Content analysis was also conducted on the data that are of qualitative nature. In conventional terms, content analyses involve description and discussion of the data. The regression model which was used was as shown below:

$\mathrm{y}=\beta 0+\beta_{1} \mathrm{X}_{1}+\varepsilon$

Equation $\mathrm{i}$ shows the relationship between the ordinary predictors $\mathrm{X}_{1}$ which are the organizational competencies and competitive advantage which is $\mathrm{Y}$.

$\mathbf{X}_{\mathbf{1}}=$ Organizational Competency

$\mathrm{Y}=$ Organizational Competitive advantage

$\mathbf{E}=$ Error term

\section{RESEARCH FINDINGS AND DISCUSSION}

From the findings based on training and development as one of the items for measuring and for achieving competencies, 75.4 percent agreed that the organization had Competitive Advantage because of organization's pursuit of continuous employee training and development. Besides, 76.7percent were in agreement that the firm had competitive advantage because of strategically having a policy on employee training and development. A proportion of 75.3percent agreed that study leave given to its employees enhanced firm's competitive advantage, and 78.8 percent agreed that planned management succession as a way of building competencies gives an organization competitive advantage. This implies that the organization should pay high premiums on development of competencies in order to set itself apart and secure competitive advantage.

In the context of knowledge /learning organization as a measure of competencies, from the results of the descriptive analysis most respondents agreed that: Staff development policy gave their firm competitive advantage, as depicted in a proportion of 83.3 percent. Many respondents agreed that recruitment of qualified employees enabled an organization to attain competitive advantage as indicated by endorsements of 73.1 percent responses; and 87.7 percent of the respondents supported the statement that when an organization encourages continuous learning it improves its competitive advantage. Seminars, conferences and workshops are often conducted as a way of employees learning new knowledge (74.8 percent). This implies that organization's learning culture is an imperative asset that a company can build, however it should be integrated with the organization's talent practice. The management's role in acquisition, conversion and application of Knowledge Management Capabilities is paramount.

Knowledge/learning in any organization is a strategic orientation that requires commitment of organization's resources. In line with capability skills from the results of the descriptive analysis most respondents agreed that recruitment policy favoring skilled applicants enhanced and organization's position of competitive advantage (76.7 percent). Majority of the respondents at 70.5 percent agreed that employee superior skills that are not easy to imitate gives the firm competitive advantage. A proportion of 70.5 percent of respondents agreed that when a firm recognizes and rewards 
competent employees it achieves competitive advantage, and 69.6 percent agreed that promotions given based on competence give a company competitive advantage.

Moreover from the analysis of variance carried out, it was clear that there was a significant relationship between the predictor variable organizational competencies and organizational competitive advantage and the relationship between the two variables existed with $p$-value of 0.000 which is less than 0.05.This implies the more banking sector improved on their organizational competencies the higher the possibility of creating and sustaining organizational competitive advantage. Moreover the findings of the regression models showed that organizational competencies were significantly related to competitive advantage in the banking sector in Uasin Gishu County. According to the model summary the model explained 62 percent of the variation or change in the competitive advantage with the remainder of 38 percent being explained by other factors other than organizational competencies. These findings set the stage for the rejection of the null hypothesis and acceptance of the alternative hypothesis that organizational competencies significantly affect organizational competitive advantage.

\section{Regression Results \\ Effect of Organizational Competencies on Organizational Competitive Advantage of the Banking Sector in Kenya.}

The goodness of fit model presented in table 8.1involves organizational competencies(X1) as the only independent variable. The outcome was: the coefficient of determination ( $R$ square) of .620. This indicated that the model explained only 62 percent of the variation or change in the dependent variable. The meaning is that when a deliberate effort is put to have strategies in place that support quest for competencies in an organization it positively drives and improves organization's competitive advantage. The remaining proportion of 38 percentcan be explained by other factors other than organizational competencies. Adjustment of the $\mathrm{R}$ square did not change the results substantially, having reduced the explanatory behavior of the predictor from 62 percentto61.8percent. This means that the model is fit to be used to generalize the findings.

Table: Goodness of Fit Model Summary

\begin{tabular}{lllllll}
\hline Model & $\mathrm{R}$ & $\mathrm{R}$ Square & $\begin{array}{l}\text { Adjusted R Std. Error R Square Durbin- } \\
\text { Square } \\
\text { of the Change } \\
\text { Estimate }\end{array}$ \\
\hline 1 & $.787^{\mathrm{a}}$ & .620 & .618 & .247 & .620 \\
Watson
\end{tabular}

a. Predictors: (Constant), organizational competencies

b. Dependent Variable: competitive advantage

The Analysis of Variance (ANOVA) results of the relationship between organizational competencies and competitive advantage of the banking sector in Kenya is ontable8.2. The results with a p-value of 0.000 being less than 0.05 , indicates that the models statistically significant in explaining the relationship between organizational competencies and competitive advantage in the banking sector 
INTERNATIONAL JOURNAL OF ACADEMIC RESEARCH IN BUSINESS AND SOCIAL SCIENCES Vol. 8, No. 10, Oct. 2018, E-ISSN: 2222-6990 ㄷ 2018 HRMARS

in Kenya. In this regard, we reject the null hypothesis that there is no significant relationship between organizational competencies and organizational competitive advantage in the banking sector in Kenya. The reflection about the factors that ensure competitiveness today reflects a movement that begins to consider competencies as a competitive differentiator (Allan \& Leandro, 2012).This implies that organizations should diagnose and make consensual needs for competencies besides identifying individual competencies and apply them with a strategic focus to engender competitive advantage.

Table 8.2: ANOVAa

\begin{tabular}{lllllll}
\hline Model & & \multicolumn{2}{l}{ Sum of Df } & Mean & F & Sig. \\
& & Squares & & Square & & \\
\hline \multirow{3}{*}{1} & Regression & 22.465 & 1 & 22.465 & 366.938 & $.000^{\mathrm{b}}$ \\
& Residual & 13.775 & 225 & .061 & & \\
& Total & 36.241 & 226 & & & \\
\hline
\end{tabular}

a. Dependent Variable: Competitive advantage

b. Predictors: (Constant), Organizational competencies

Regression Coefficients of Organizational Competencies and Competitive Advantage

Table 8.3 presents the regression results of organization competencies on Competitive Advantage of banking sector in Kenya. With a constant $(p$-value $=0.000)$ of 1.791 , the study concluded that even without organizational competencies, the banking sector seemed to display some form of Competitive Advantage. Nonetheless, the gradient coefficient of .565indicated the extent to which a unit changes in organizational competencies (OC) caused a change in competitive advantage (CA). In this case, a unit change in OC leads to .565units of positive change in CA of the banking sector. Therefore, the organization competency and Competitive Advantage model can now be presented as follows:

$Y=1.791+.565 X 1+\varepsilon$,

T-test was used to identify whether the predictor was making a significant contribution to the model. When the $t$-test associated with $B$ value is significant then the predictor is making a significant contribution to the model. The results show that Organizational Competencies $(t=19.156, P<0.05)$. This means that organization competencies was significant ( $p$-value $=0.000$ ) in positively influencing the Competitive advantage of banking sector in Kenya. 
INTERNATIONAL JOURNAL OF ACADEMIC RESEARCH IN BUSINESS AND SOCIAL SCIENCES Vol. 8, No. 10, Oct. 2018, E-ISSN: 2222-6990 @ 2018 HRMARS

Table: Coefficients of Organization Competencies and Competitive Advantage

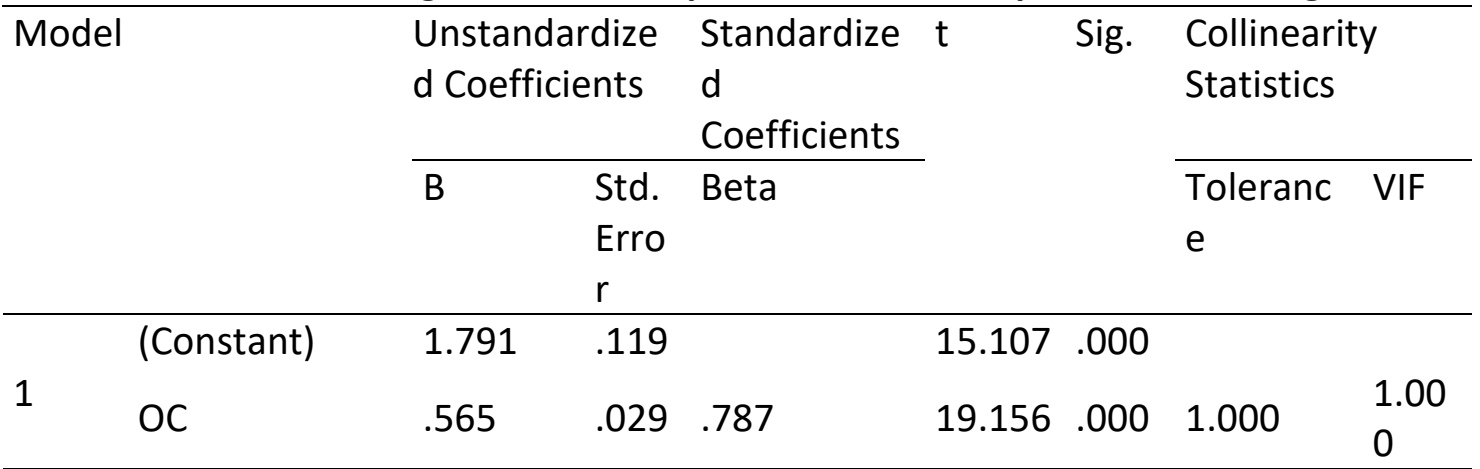

a. Predictors: (Constant), Organizational Competencies

b. Dependent Variable: Competitive Advantage

\section{Test of Hypothesis}

$\mathrm{Ho}_{1}$ : Organizational Competencies do not have Significant Effect on Organizational Competitive Advantage in the Banking Sector in Kenya.

The regression results indicated that organization competencies explained 62 percent $\left(R^{2}=0.620\right)$ variation in competitive advantage. $P$ value of 0.00 significant at 5 percent confidence level, indicate that the overall regression model is significant. This reveals that organization competencies have a significant influence on organizational competitive advantage. Therefore, the null hypothesis was rejected, hence it is confirmed that for each unit increase in organization competencies there is 0.565unit increase in organization's competitive advantage. The influence of organization competencies was stated by the t-test value of 19.156, which implies that the standard error associated with the parameter warrants the rejection of the null hypothesis. The closer the $T$ is to 0 ; the more likely there isn't a significant difference. These findings corroborates the fact that hiring competent employees and continuously developing those competencies through effective human resource practices, underpins organizational capability which begets organizational advantage.

The rejection of the null hypothesis was underpinned by the findings of both the current study and findings of (Nimsith, Rifas \& Cader, 2016; Sabah, Laith \& Manar, 2012; Bani-Hani \& Al-Hawary, 2009)who assert that core competence has a strong and positive impact on competitive advantage and organizational performance. This implies that organizations should adapt as well as craft the nonimitable competencies to match the dynamic environment in which they operate so that they can achieve competitive advantage. Therefore, this study submits that core competencies is and remains a vital determinant of competitive advantage.

\section{CONCLUSION AND RECOMMENDATIONS}

The study established existence of strong organization competencies within the banking sector in Kenya. The banks have developed unique competencies in training and development, knowledge /learning organizations and capabilities/skills which have given them the ability to effectively fulfill their mandate. The theoretical implication of this study is that it supports and extends the resource based view, stakeholder theories and Michael Porter's theory on a longitudinal view as it has casted 
INTERNATIONAL JOURNAL OF ACADEMIC RESEARCH IN BUSINESS AND SOCIAL SCIENCES

Vol. 8, No. 10, Oct. 2018, E-ISSN: 2222-6990 @ 2018 HRMARS

more light on competencies as a means through which an organization can attain a sustainable competitive advantage. This finding supports the essence of value, rarity, non-imitability for purposes of galvanizing competitive advantage.

The study also showed that organization competencies are significantly affect competitive advantage of banking sector in Kenya.

The study recommends that organization should develop a holistic approach of implementing overall organization competencies which include staff training and development strategies which focus on dynamic capabilities for sustained competitive advantage. Secondly organizations should foster a learning organization culture coupled with talent management practices remain imperative for continuous competitive advantage. At the same time, the banking sector should hire and develop talent among their staff in order to synergize their contribution within the resource bundle of the firm for sustained competitive advantage. Organizations are encouraged to strategically make policies oriented towards achievement of competitive advantage through organizational competencies.

\section{References}

Achua, C., \& Lussier, R. N. (2011). An Exploratory Study of Business Students' Discretionary Social Responsibility Orientation. Small Business Institute ${ }^{\circledR}$ Journal, 1(1).

Achua, J. K. (2008). Corporate Social Responsibility Practices in Nigerian Banking System. Society and Business Review, Vol. 3 Iss: 1 pp. 57-71.

Acıkdilli, G., \& Ayhan, D. Y. (2013). Dynamic capabilities and entrepreneurial orientation in the new product development. International journal of business and social science, 4, 144-150.

Adeleke, C. J. (2014). Corporate Social Responsibility In Nigeria Banking Sector . Walden Scholarly Works, 1-139.

Adler, P. S., \& Kwon, S. W. (2002). Social Capital: Prospects For A new Concept. Academy of Management Review, 27 (1), 17-40.

Adom, A., Nyarko, I., \& Som, G. N. (2016). Competitor Analysis in Strategic Management: Is it a Worthwhile Managerial Practice in Contemporary Times? . Journal of Resources Development and Management , 24.

Agha, S., Alrubaiee, L., \& Jamhour, M. (2011). Effect of core competence on competitive advantage and organizational performance. International Journal of Business and management, 7(1), 192.

Alimin, I. I., Raduan, C. R., Jegak, U., \& Haslmda, A. ( 2012). The effects of organizational resources, capabilities and systems on competitive advantage. International Business Management, 6(2), 176-186.

Alimin, I., Raduan, C., Jegak, U., \& Haslinda, A. (2012). The relationship between organisational resources, capabilities, systems and competitive advantage. asian academy of management journal, 17, ( 1) 151-173,.

Azmi, R. A. (2006). Business Ethics as Competitive Advantage for Companies in the Globalization Era . Retrieved March 25, 2018, from Available at SSRN: https://ssrn.com/abstract=1010073 or http://dx.doi.org/10.2139/ssrn.1010073

Azmi, R. A. (2006). Business ethics as competitive advantage for companies in the globalization era. 
INTERNATIONAL JOURNAL OF ACADEMIC RESEARCH IN BUSINESS AND SOCIAL SCIENCES

Vol. 8, No. 10, Oct. 2018, E-ISSN: 2222-6990 @ 2018 HRMARS

Baba, Y. (2012). Adopting a specific innovation type versus composition of different innovation types

Case study of a Ghanaian bank. . International Journal of Bank Marketing, 30(3),218-240.

Bučiūnienè, I., \& Kazlauskaitè, R. ( 2012). The linkage between HRM, CSR and performance outcomes. . Baltic Journal of Management, 7(1), 5-24.

Cameron, C., \& Miller, D. L. (2015). A Practitioner's Guide to Cluster-Robust Inference. Journal of Human Resources , 50(2), pp. 317-372.

Cania, L., \& Korsita, B. (2015). Knowledge Management: The Key to Sustainability of Economic Crisis. Mediterranean Journal of Social Sciences, 6(1 S1), 548.

Carfagna, E., \& Arti, V. B. (2007). Crop area estimates with area frames in the presence of measurement errors. Proceeding of ICAS-IV, Fourth International Conference on Agricultural Statistic. Invited paper, (pp. (pp. 22-24)). Beijing.

Cavana, R., Delahaye, B., \& Sekeran, U. (2001). Applied Business Research: Qualitative And Quantitative Methods. UK: Wiley, Brisbane.

Dartey-Baah, K. (2011). Exploring the limits of Western corporate social responsibility theories in Africa. International Journal of Business and Social Science, 2(18).

Dave, U., \& Dale, L. (1991). Organizational capability: creating competitive advantage . Academy of Management Executive, vol 5 No. 1.

Eeman, B., Rabindra, K., \& Lalatendu, K. (2015). Organizational Citizenship Behaviour, Job Performance and HR Practices: A Relational Perspective. Management and Labor Studies, 39.

Ehrhart, M. G. (2004). Leadership and procedural justice climate as antecedents of unit level organizational citizenship behavior. Personnel Psychology, 57, 61-94.

Field, A. (2009). Discovering statistics using SPSS: and sex and drugs and rock ' $n$ ' roll (3rd edition). London: Sage.

Field, A. P. (2005). Is the meta-analysis of correlation coefficients accurate when population correlations vary? Psychological methods, 10(4), 444.

Flynn, B., Sakakibara, S., Schroeder, R., Bates, K., \& Flynn, E. ( 1990). Empirical research methods in operations management. Journal of Operations Management, 9(2), 250-84.

Furrer, O., Tomas, H., \& Goussevskaia, A. (2008). The structure and evolution of the strategic management field: A content analysis of 26 years of strategic management research. International Journal of Management Reviews, 10(1): 1-23.

G.O.K. (2008). First Medium Term Plan (2008-2012: Kenya Vision 2030. Nairobi: Government Press.

Green, P., Tull, D., \& Albaum, G. (1988). Research for Marketing Decisions.(5th ed.). New Jersey: Prentice Hall.

Gregory, R. ( 2000). Psychological Testing. (3rd ed.). MA: Allyn \& Bacon.

Gualtieri, I., \& Topić, M. (2016). Exploring corporate social responsibility's global and Glocal practices in Qatar: A practitioner and stakeholder perspective. Arab Economic and Business Journal, 11(1), 31-54.

Gugler, P., \& Shi, J. Y. (2009). Corporate social responsibility for developing country multinational corporations: lost war in pertaining global competitiveness? . Journal of Business Ethics, , 87(1), 3-24. 
INTERNATIONAL JOURNAL OF ACADEMIC RESEARCH IN BUSINESS AND SOCIAL SCIENCES

Vol. 8, No. 10, Oct. 2018, E-ISSN: 2222-6990 @ 2018 HRMARS

Hummaira, Q. Y., Iftikhar, A., Ali, S., \& Muhammad, I. (2016). Impact of Internal Corporate Social Responsibility on Employee Engagement a Study of Moderated Mediation Model. International Journal of Sciences Basic and Applied Research , 30( 5) 226-243.

Inmyxai, S., \& Takahashi, Y. (2010). The effect of firm resources on business performance of male and female headed firms in the case of Lao microsmall and medium. International Journal of Business and Information, 5(1).

Iraya, C., \& Jerotich, O. ( 2013). The relationship between cooperate social responsibility practices and financial performance. International Journal of Economics, Finance and Management Science, 2(1),84-91.

Kang, Y. T., \& Daniel, M. C. (2012). Recruitment and Competitive Advantage: A Brand Equity Perspective Volume 1 Handbook of Organizational Psychology,. Oxford.

Karande, K., Rao, C. P., \& Singhapakdi, A. (2002). Moral philosophies of marketing managers: A comparison of American, Australian, and Malaysian cultures. European Journal of marketing, 36(7/8), 768-791.

Lau, R. S. (2002). Competitive factors and their relative importance in the US electronics and computer industries. International Journal of Operations \& Production Management, 22 (1): 125-135.

Laxmikant, M. (2014). Human resource systems and competitive advantage: an ethical climate $\begin{array}{lllll}\text { perspective. } & \text { Retrieved } 09, & 018, & \text { from }\end{array}$ https://onlinelibrary.wiley.com/doi/abs/10.1111/beer.12069

Leeora, D. B., \& Charmine, E. J. (2004). The five capabilities of socially responsible companies. Journal of Public Affairs, Volume 4, Issue 2, pages 125-144.

Lemon, K. N., John, R., Russell, S. W., \& Priya, R. (2010). Why, When, and How Should the Effect of Marketing Be Measured? A Stakeholder Perspective for Corporate Social Responsibility Metrics. Journal of Public Policy and Marketing.

Leonidou, L., Fotiadis, T., \& Leonidou, C. (2013). Resources and capabilities as drivers of hotel environmental marketing strategy: Implications for competitive advantage and performance. Tourism Management, 35, 94-110. ISSN 0261-5177.

Madueño, J. H., Jorge, M. L., Conesa, I. M., \& Martínez-Martínez, D. (2016). Relationship between corporate social responsibility and competitive performance in Spanish SMEs: Empirical evidence from a Stakeholders' perspective. BRQ Business Research Quarterly, 19(1), 55-72.

MaHoney, J. T., Anita, M. M., \& Christos, N. P. (2009). The Interdependence of Private and Public Interests. Organization Science, 20(6), 1034-1052.

Maier, R., \& Remus, U. U. (2002). Defining process-oriented knowledge management strategies. Knowledge and Process Management, vol. 9, no.2, pp.103-118.

Mei, P. L., \& Seng, F. (2015). The role of internal corporate social responsibility in professional service sector: an empirical study fromKlang Valley, Malaysia. Asia Paciflc Journal Of Advanced Business and Social Studies, 1(1).

Meutia., \& Ismail, T. (2012). The Development of Entrepreneurial Social Competence And Business Network to Improve Competitive Advantage And Business Performance of Small Medium Sized Enterprises: A Case Study of Batik Industry In Indonesia. . Procedia - Social and Behavioral Sciences, , 65, $46-51$. 
INTERNATIONAL JOURNAL OF ACADEMIC RESEARCH IN BUSINESS AND SOCIAL SCIENCES

Vol. 8, No. 10, Oct. 2018, E-ISSN: 2222-6990 @ 2018 HRMARS

Mugesani, P. A. (2018). "Role of Corporate Social Responsibility Activities on Employees' Commitment to Firms Listed at Nairobi Stock Exchange in Kenya. PhD diss., JKUAT.

Mugo, I. N. (2016). Effect of organizational core competences on performance in the insurance industry in kenya.Strategic Journal of Business \& Change Management, 3(4).

Muhammad, A. F., Budiman, C., \& Lena, E. (2014). The Effect of Organizational Citizenship Behavior (OCB), Total Quality Management (TQM), Technology Leadership and Service Quality on the Performance of Private Universities in Surabaya . Academic Research International , 5(2) .

Muhammad, F., \& Abdul, A. (2015). Learning organization and competitive advantage an integrated approach.Asian Economic and Social Society, 5(4),73-79.

Murillo, R. H., Martinek, C. J., \& Hernandez, R. (2009). Corporate Social Responsibility can be Profitable. Business.

Murray, P. (2000). Designing for business benefits from knowledge management . In C Despres \& D Chauvel (eds), Knowledge Horizons: The Present and the Promise of Knowledge Management (pp. pp.171-194.). Boston: Butterworth-Heinemann.

Mutunga, S., Minja, D., \& Gachanja, P. (2014). Resource Configurations on Sustainable Competitive Advantage of Food and Beverage Firms in Kenya: A Resource Based View of the Firm . European Journal of Business and Management , 6, (24).

Nimsith, S., Rifas, A., \& Cader, M. (2016). Impact of Core Competency on Competitive Advantage of Banking Firms in Sri Lanka. International Journal of Scientific Research and Innovative Technology, 3 (7).

Nkundabanyanga, S. K., \& Okwee, A. ( 2011). Institutionalizing corporate social responsibility (CSR) in Uganda: does it matter? Social Responsibility Journal , 7(4), 665-680.

Noe, R., Hollenbeck, J., Gerhart, B., \& Wright, P. (2010). Human resource management: Gaining a competitive advantage (7th ed.). New York: McGraw-Hill Irwin.

Nuzzo, R. (2014). Statistical errors: $P$ values, the 'gold standard' of statistical validity, are not as reliable as many scientists assume. . Nature, 506(150), 150-152. doi: 10.1038/506150a.

O'Leary, Z. (2014). The essential guide to doing your research project (2nd ed.). London: SAGE.

Ofori, D. F., NyuurR, B., \& S-Darko, M. (2014 ). Corporate social responsibility and financial performance: Fact or fiction? A look at Ghanaian banks',. Acta Commercii, 14(1), 1-11.

Oh, S., Hong, A., \& Hwang, J. ( 2017). An Analysis of CSR on Firm Financial Performance in Stakeholder Perspectives. Sustainability, 9(6), 1023.

Okpara, J. O. (2015). Exploring the Effects of Intangible Resources on Competitive Advantage and Performance of Listed Firms in Nigeria. International Journal of business and applied science, 4(2).

Omerzel, D. G., \& Rune, E. G. (2011). Knowledge Resources and Competitive Advantage. Managing Global Transitions, 9 (4): 335-354.

Phusavat, K., \& Kanchana, R. ( 2007). Competitive priorities of manufacturing firms in Thailand. 107. Industrial Management \& Data Systems, , 107(7),979-996.

Piantadosi, J., Howlett, P., \& Boland, J. (2007). Matching the grade correlation coefficient using a copula with maximum disorde. Journal of Industrial and Management Optimization, Vol. 3 (2), pp. 305 - 312. 
INTERNATIONAL JOURNAL OF ACADEMIC RESEARCH IN BUSINESS AND SOCIAL SCIENCES

Vol. 8, No. 10, Oct. 2018, E-ISSN: 2222-6990 @ 2018 HRMARS

Poornima, M. (2015). Achieving Competitive Advantage through Employees. International Journal for Arts Management and Humanity studies , 1,(9).

Porter, M. (2001). Strategy and the Internet. Harvard business review, 79(3), 62-78.

Porter, M. E. (2011). Competitive advantage of nations: creating and sustaining superior performance (Vol. 2). . Simon and Schuster.

Ray, G., Barney, J. B., \& Muhanna, W. A. ( 2004). Capabilities, business processes, and competitive advantage: choosing the dependent variable in empirical tests of the resource-based view. Strategic management journal, 25(1), 23-37.

Rosa, M. M., \& María, Y. S. (2011 ). Training as a source of competitive advantage: performance impact and the role of firm strategy, the Spanish case, The. International Journal of Human Resource Management, 22:3, 574-594, .

Rose, R. C., Abdullah, H., \& Ismad, A. I. (2010). A review on the relationship between organizational resources, competitive advantage and performance. The journal of international social research, 3(11), 487-498.

Runkel, P. ( 2017). Cp and Cpk: Two Process Perspectives, One Process Reality. Retrieved from http://blog.minitab.com/blog/statistics-and-quality-data-analysis assesed on 23/2/2017

RYSZARD, B. ( 2014). Strategic Management: Formulation and Implementation. Retrieved April 23, 2018, from http://www.strategy-formulation.24xls.com/en531

Sabah, A., Laith, A., \& Manar, J. ( 2012). Effect of Core Competence on Competitive Advantage and Organizational Performance. International Journal of Business and Management, 7(1).

Sanifa, H. S. (2015). Competitive Strategies and Porter's Five Forces Model By The Insurance Companies In Kenya. .

Saunders, M., Lewis, P., \& Thornhill, A. (2007). Research Methods for Business Students (4th ed.). London: Pearson.

Saunders, M., Saunders, M., \& Thornhill, A. (2011). Research Methods For Business Students. Pearson Education India.

Schein, E. H. (2010). Organizational culture and leadership (Vol. 2) . John Wiley \& Sons.

Simard, Doucet, \& Bernard. (2005). Pratiques en GRH et engagement des employees. Le role de la justice. HRM Practices and employee commitment: the role of justice. Industrial Relations, 60(2):296-319.

Sincero, S. M. ( 2012). Pilot Survey. Retrieved 07 25, 2018, from Explorable.com: https://explorable.com/pilot-survey

Sirmon, D. G., Hitt, M. A., \& Ireland, R. D. (2007). (2007). Managing firm resources in dynamic environments to create value: Looking inside the black box. . Academy of Management Review , 32(3) ,273-292.

Tabachnick, B. G., \& Fidell, L. S. (2007). Using multivariete statistics (5th Edition). Boston: Pearson Education Inc.

Turker, D. (2009). Measuring Corporate social responsibility: A scale development study . Journal of Business Ethics, 85,411-427.

Turnipseed, D. L., \&\& Rassuli, A. (2005). Performance Perceptions of Organizational Citizenship Behaviours at Work: a BiLevel Study among Managers and Employees. British Journal of Management, 16, 231-244. 
Wang, H. L. (2014). Developing and testing a new framework for strategic alignment.

Wang, H.-L. (2013). Being practical with theory: a window into business research: Theories for Competitive Advantage. THEORI Research Group, University of Wollongong.

Wang, W. C., Lin, C. H., \& Chu, Y. C. (2011). Types of competitive advantage and analysis. International Journal of Business and Management, 6(5), 100.

Warf, F. \& Stutz, B. (2007). The World Economy: Resources, Location, Trade and Development (5th ed.). Upper Saddle River: Pearson.

Wright, P. M., Dunford, B. B., \& Snell, S. A. (2005). Human resources and the resource based view of the firm. Strategic human resource management: Theory and practice, 17-39.

Yuen, K. F., \& Lim, J. M. (2016). Barriers to the implementation of strategic corporate social responsibility in shipping. The Asian Journal of Shipping and Logistics, 32(1), 49-57. 